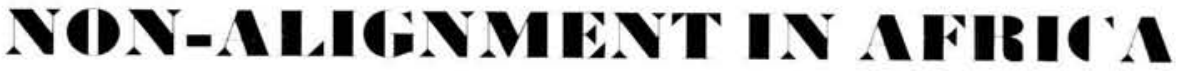

\section{(i dareobs}

\section{The historical setting}

The first indications to the Western world that African non-alignment had achieved conscious political form became apparent only in the late 1940's. This strand of thought within the tapestry of Africanism reached its zenith with the declarations of Kwame Nkrumah, Jomo Kenyatta and Julius Nyerere in the years after the Pan-African Congress in Manchester in 1945. The causes of the movement go back far beyond the first official expressions of an African solidarity in the 1940's. As a mature expression of group attitudes towards foreign policy, nonalignment can be traced back to the roots of African nationalism.

At its earliest stage African nationalism was the product of a heightened intellectual activity on the part of Westernised elites in the colonies. The new intellectual activity centred on a reexamination of indigenous values and cultures, using form of reference supplied by Western political thought. This tendency was exacerbated by World War One which brought about the weakening of the colonial powers and the emergence of liberal and radical thought as an international political factor - on the one side expressed in US President Woodrow Wilson's principle of national self-determination and at the Bolshevik extremity, by Lenin's denunciations of imperialism.

The intellectual ferment among the African elites led to attempts to organise political movements. Though isolated from one another, they developed virtually identical objectives, namely, the search for a new African personality and, closely linked with it, freedom from colonial domination. These two objectives formed the premise on which African nationalism rested.

There was, however, very little horizontal co-operation among the various nationalist movements. Each of them arose and developed according to the conditions prevailing in the particular areas in which it formed. This naturally led to a broad diversification in the character of these movements, despite the uniformity of their basic objectives.

The advent of World War Two had a revolutionary impact on colonialism. The Zimbabwe Nationa- list leader, Rev Ndabaninge Sithole. describes the process in the following words:

World War Two ... has had a great deal to do with the awakening of the peoples of Africa. During the war the African came in contact with practically all the peoples of the earth. He met them on a life-and-death struggle basis. $\mathrm{He}$ saw the so-called civilised and peaceful and orderly white people mercilessly butchering one another just as his so-called savage ancestors had done in tribal wars. He saw no difference between the primitive and the civilised man. In short, he saw through European pretensions that only Africans were savages. This had a revolutionary psychological impact on Africa. But more than this, World War Two taught the African most powerful ideas. During the war the Allied Powers taught the subject peoples that it was not right for Germany to dominate other nations. They taught the subjugated peoples to fight and die for freedom rather than live and be subjugated by Hitler.

The consequences were iminent. In the African colonies the immediate post-war years were marked by a period of heightening political, social and economic instability. The hundreds of thousands of African ex-servicemen, who had served both in the British army and with the Free French, returned home with ideas which were often diametrically opposed to the traditionalist values that had governed their lives in the pre-war era.

Their political demands found full expression in the Manchester Congress held in 1945. For the first time a Pan-African Congress demanded outright independence for Africa and threatened the use of force if independence was denied them, and voiced its solidarity with independence movements in Asia.

\section{The political setting: search for a foreign policy}

Several factors were at work which led to the creation of a Third World ideology opposed to alignment with either of the superpowers.

The common denominators which brought about in Africa a community of interests in foreign affairs rest on social and economic factors, and 
on a psychological element. In the first category the bonds are caused by underdevelopment:

Much less than Marxism - Leninism, it is . . the consciousness of solidarity in poverty, the weakness of the standard of living, the inadequacy of the public services, the presence of all the elements characteristic of the underdeveloped that provide the most solid foundation for the new proletariat.

Less tangible but having no less an effect, is the psychological element in the feeling that a racial bond unites the non-white peoples. Superimposed on these two basic denominators which might lead to a community of fundamental interests are the historical-political factors, foremost amongst which is the common heritage of colonial subjugation and the concomitant struggle for national independence.

Once independence has been achieved new political problems arise which create additional common factors for most of the African countries. In all too many cases there exists very little relationship between political independerice and economic viability. The evils of political strings attached to economic aid, of neocolonialism, of a continuing dependence on the donor country, which is generally the former colonising power, are difficult for the newly independent states to swallow. It is not difficult to understand then why assertions of independence should be so important to the Afro-Asian countries.

Faced with staggering economic and social problems at home, the new leaders generally find it easier to seek a means of expressing their independence externally. One such means is the United Nations - to be dealt with later. Another means is by association with other states on an equal footing. There exists a strong desire for solidarity, even of brotherhood, to act as a buttress to one's limited strength. This serves as a powerful stimulant to non-alignment.

There exist two diametrically opposed attitudes to the cold war among Afro-Asian countries, both of which have played a dominant role in the foreign policy orientations of the countries of the two continents. The one, expounded by India, views the rivalry between the two power blocs as a constant threat to world peace. According to this, view the cold war must be neutralised. The second attitude is rarely expounded publicly, but is ever present in the foreign policy calculations of certain African countries, notably Egypt: as long as the cold war exists the countries of Asia and Africa are assured of outside support, as both world blocs seek to buy political gain. However, since any detente in the cold war could lead to a dividing up of the world into spheres of influence between the two blocs, which is one of the possibilities most to be feared, there are a number of tangible advantages to a continuation of the cold war.

It is significant that in neither of these two approaches to the cold war does the ideological factor play a preponderant role. It is not the choice between the Communist and Capitalist systems which determines the attitude of the majority of countries of Africa and Asia to the cold war, but much more pragmatic factors. Moreover, both Communism and Western-style democracy were found to be ill-suited and alien.

It was Nehru of India who insisted that there was room for a third ideology, and that there is a third way which takes the best from all existing systems... and seeks to create something suited to one's own history and philosophy.

Thus two approaches to the cold war, and the general rejection of the two dominant world; ideologies, form the backdrop to the political behaviour of the countries of Africa with regard to the two world blocs:

a. The overriding need for world peace and

b. the advantages to be gained in perpetuating the balance between the Communist and the Capitalist world systems.

But neither of these attitudes are concomitant with membership of one of the two world blocs, and both objectives can be attained only if the new countries remain outside the sphere of influence of either of the two Systems. There thus exist powerful motives for the formal nonadherence to either the Western or the Communist blocs - these have characterised the foreign policy orientations of the majority of African countries.

The general trend in Africa has thus been one of non-adherence to power blocs, or, to use the more fashionable term, of non-alignment: no regular, permanent and automatic taking of sides in the cold war, whether for reasons of ideology. benefit or pressure.

There are a few more concrete reasons for non-alignment. One is the emphasis placed by 
the newly independent countries on their full political independence and their need to assert it. Since the Western and Communist blocs are, obviously, dominated by the USA and USSR, relations within the blocs are very unequal. A member of a bloc is obliged to judge issues according to the interests of the bloc and not according to its own national interests.

There existed an additional motive in the choice of non-alignment - that of playing one bloc against the other and gaining aid from both, which was found to be more advantageous than being allies of one bloc only. The Soviet Union, particularly in the post-Stalin era, placed great emphasis on economic aid to non-aligned countries of Asia and Africa. These countries were thus offered a choice, an alternative to their former colonising countries; moreover there existed an opportunity to obtain aid from both blocs at the same time, as was, for example, demonstrated by Egypt and later by Tanzania.

In the context of examining whether a community of fundamental national interests of the peoples of Africa exists, and how this has determined foreign policy orientations, non-alignment and non-adherence can be generally described as a typical foreign policy orientation of African countries.

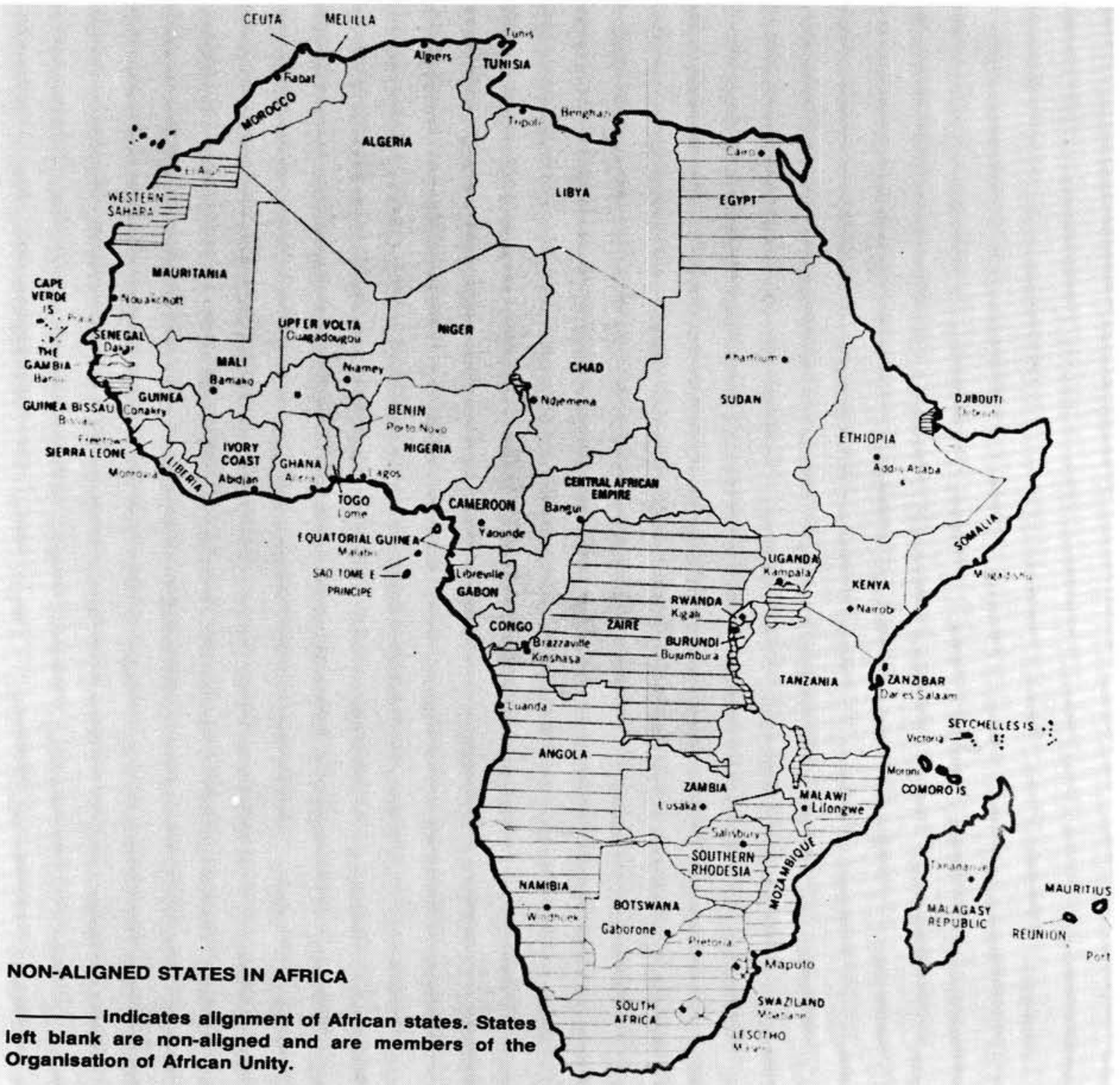




\section{Africa and non-alignment}

Obviously, then, the African states could not shut themselves off from the problems of the world. They could not be isolationist, if only because of their urgent need of foreign aid and because they canvassed for support for the non-independent territories in Africa. They therefore had to develop foreign policy attitudes beyond immediate African questions. Above all, this process was exacerbated because the cold war conflicts did not bypass Africa. The Congo crisis, in particular, and the subsequent embroilment of the great powers forced the Africans to take a stand regarding two opposing approaches, which eventually found expression in the rival association of African countries into the military anti-colonial 'Casablanca' and moderate 'Monrovia' groups.

This polarisation into two opposing units did not, however, mean that each group openly supported one of the two sides in the cold war. Virtually all the African States, of whatever political persuasion, professed to follow a policy of non-alignment vis-a-vis the great power conflict. There exist scores of statements and declarations by the majority of African leaders on the virtues of non-alignment. Yet, this much-used term covers a multitude of foreign policy postures. A number of African countries such as Senegal, the Ivory Coast, Chad, Kenya and Nigeria, to mention only some, had foreign troops on their soil or their armies were commanded by officers of their former colonisers. The regimes of others - Kenya, Uganda, Tanzania and Gabon - were propped up with the help of troops from Great Britain or France when rioting and rebellion threatened to overthrow them, and yet professed to be non-aligned. Still others followed a policy consistently hostile to one of the two world blocs.

Despite these anomalies, however, the majority of African leaders followed, by self-definition, a non-aligned policy in that they had no wish to become involved in issues which they did not consider to be their own; non-alignment became a means enabling Africa not to be drawn 'into areas of conflict which so far have not spread south of the Sahara'.

Over and above the desires of most Africans to be non-committed in cold war conflicts, three factors more than any others influenced their foreign policy. These were: a. the degree to which an African regime was willing to accept some form of presence of the former colonial power in exchange for hastening on the process of raising its country's standard of living;

b. the degree to which foreign aid received by an African regime was conditional upon its following certain foreign policy lines;

c. the stand taken by non-African states on colonialism in general and on the liberation of the non-independent African territories in partịcular.

These three factors, then, link up with the stand of African states on non-alignment adopted by each country, and provide the weight which tips the balance in favour of one power bloc or the other.

\section{Non-alignment at the OAU}

After having shaken off the yoke of colonial domination, nothing was more natural than for the newly independent states to define their own policies in all domestic and international affairs. Some of them continued very close and cordial relations with the former colonial power, whereas others broke completely and turned elsewhere for friends and allies. But none of the states wished to find itself again in a position where it could not determine its basic options alone. By insisting to be the masters of their own destinies. all the African States considered themselves to be non-aligned.

Whether or not this was true for each individual state, it was valid for them all when they acted as a unit. Since some leaned one way and some another, the tendencies cancelled out and Africa as a whole could find a policy that, if not always equal distant from the blocs, at least followed none closely. In order to determine its own course, Africa needed a forum where each state would be able or would be encouraged to cast aside its external connections for the sake of the continent. This was one of the services the Organisation of African Unity hoped to render.

Originally, non-alignment - as conceived of by its founders and philosophers - was a stance somewhere between that of the major blocs. In practice, it was rarely in the middle, but at least there was considerable leeway for choice. To avoid serious conflict, the uncommitted states tried to find a peaceful solution or compromise for each issue. This was not neutrality or passiveness, and an active policy was to be 
proposed on each matter. Nevertheless, any action was always on the terms of the two super-powers. Driven by repulsion rather than attraction to American and Soviet Policies, the non-aligned group could still do nothing more at the $\mathrm{OAU}$ than propose solutions to the problems raised by others and then await the ultimate approval or rejection of their solutions. Against this background, the Charter of African Unity laid down its final principle: affirmation of a policy of non-alignment with regard to all blocs, but gave no indication of what this meant in practise. Some of the blanks were filled in by a resolution on non-alignment adopted by the Council of Ministers in February 1964. On the one hand it recalled the importance of co-existence between different systems of government and ideologies and the need to maintain international peace and security. On the other, it stressed more specific concerns such as the unity and solidarity of the member stakes and the freedom, stability and prosperity of Africa. To attain these various aims it was recommended that the African states cease their commitments as soon as possible and follow a co-ordinated, non-aligned foreign policy. Such a policy would be prepared by direct consequences.

But the only attempt at active measures stemmed from the summit conference's resolution on general disarmament. On a world level, it appealed to the great powers and, in particular, the Soviet Union and the United States, to reduce their conventional weapons, end the arms race and sign an agreement for general and complete disarmament under strict and effective international control. It also objected to the accumulation of nuclear weapons and their testing and urged greater efforts for the peaceful use of atomic energy. On the other hand the internal situation demanded the end of military occupation of the African continent and the elimination of military bases and nuclear tests. It also affirmed the principle of making Africa a nuclear-free zone. A year later, at the Cairo Assembly, the Heads of State adopted a 'Declaration for the Denuclearisation of Africa', in which they solemnly expressed their will 'not to manufacture or acquire control of nuclear weapons'.

The desire to free Africa of all foreign interference was the origin behind the establishment of the Organisation of African Unity - a parallel to the impulse which led to the spread of PanAfricanism.

The Cairo Assembly laid down the ground rules of a new, more specifically African nonalignment - in effect the prototype principles which formed the constitutional basis of the OAU. Member states were warned to avoid all commitments that tended 'to inject into Africa foreign rivalries or bloc politics'. This, of course, did not mean that they could not enter into agreements for their defence, freedom or development with outside powers. However, they had to see to it that such undertakings did not 'threaten the peace, tranquillity and development of Africa as a whole ... or interfere with the rights, freedom and integrity of other African states'. The members also had to discourage the cold war actively. In their relations with non-African countries and especially the major powers, they

shall at each and every opportunity restate the determination of Africa not to become involved in foreign disputes or conflicts, nor to become the battlefields in any fight for world power, and not to allow any African region, State or problem to become part of any struggle for world power.

In practice, however, it often proved difficult to avoid involvement. One standing invitation to foreign interest was the continued need for economic assistance in all independent countries. When it came to development, the whole African community (including those most bitterly attacking neo-colonialism) realised that essential aid could only be obtained from the more advanced and prosperous part of the world. Financial and technical assistance was repeatedly requested and granted. Furthermore, this spread into areas like defence and military support, which has major implications for non-alignment. Although the African states asked that aid be given without strings, it was difficult to keep from drawing closer to one's benefactors.

This danger was also connected with decolonisation, for the continent was not strong enough to emancipate the remaining territories itself moreover the liberation movements needed substantial funds and equipment. What they could not obtain in Africa they had to seek elsewhere. This meant that if more backing came from one side than from the other, a growing indebtedness arose towards one of the blocs.

\section{OAU: The dangers of ideology}

The most serious invitation to outside interest arose when conflicts broke out on the continent. If 
these disputes had a local basis, with sufficient goodwill and some give-and-take a solution could be found. However, if some global ideology became included in a dispute, a distortion of values, particularly distressing in Africa, occurred. Since basic views did not differ drastically from country to country, and since all the states had escaped from colonialism, belonged to an anti-colonial group and fought more or less zealously for a 'liberation' of the continent, and since all sought to develop the economy and modernise society, none of the African States were strict adherents to either capitalism or communism, or denied the virtues of democracy; most proclaimed some sort of African Socialism and had one-party states. Their similarities were great enough for them to support the broad African ideology of the Charter of African Unity. There should then have been no reason for extraneous or irreconcilable ideological quarrels.

Nevertheless, ideology could not be entirely avoided. There were differences on policy and outlook: disparities in wealth, the needs of an economy drove a country to seek help in differing corners. Many an African leader increased such differences by trying to give an impetus to their countries through a national ideology - this could be further complicated by rigidity in the body politics due to the one-party system. In addition, governments willing to maintain relations with both East and West externally were rarely willing to permit differences of opinion at home. It became apparent, then, that the danger to African unity was greatest wherever a conflict between African states or within one state was combined with an ideological purpose. In such cases, the country and continent rapidly fell into rival groups. A slide towards cold war confrontation could occur when one side, often the weaker, appealed to a friendly power already aiding it, to make an increasing effort in the moment of crisis. Being desperate, the African state might have to accept more constraining conditions than it would ordinarily be willing to bear. If the Super-power was afraid of reversal in the local of general balance of power, it could force aid on its protégé. The result, if such support were forthcoming, was that the African adversary would be given persuasive reason to solicit and possibly to obtain backing from the opposing bloc. Escalation would soon follow. The greatest danger of interference was thus connected with conflicts outside Africa. The task of the Organisation of African Unity was not only to find a solution or a compromise to a dispute but also to avoid contagion and disruption from the outside world.

Furthermore, the introduction of foreign interest into an African conflict often meant an escalation in scale of means of destruction. The relatively poor African countries with small armies and limited equipment could not fight as long or cause as much damage to each other as they could with the powerful weaponry of outside backers. With a steady stream of arms and material the struggle could be drawn out and deadly. Finally, if a solution were found to such a conflict, it would largely reflect an imposition, by force of arms, of the larger power - more interested in their own relations than the merits of the situation or the good of Africa. Having ignored the realities or the demands of the African context, the solution was likely to be unstable and always in danger of being contested or re-opened. After the Congo debacle, for example, there was a strong aversion to all foreign intervention, and nonalignment was given a special meaning. It was clearly directed outwards and aimed, via the $\mathrm{OAU}$, at shielding the continent so that Africans could settle their own problems.

Originally, non-alignment was just a broad principle of the newly independent states and the line which they attempted to follow was more often than not uncertain and contested. The Organisation of African Unity, did not, however, become a body to inspect and approve the policies of its members in foreign affairs. Rather it tried to protect Africa from outside interference at critical moments.

The value of non-alignment, as part of OAU policy, was conceded explicitly or tacitly by much of the world community. The clearest success was with the United Nations. Under Articles 52 and 53 of its Charter, regional bodies such as the OAU were given a role in the settlement of disputes and a lesser one for the maintenance of peace. But it was not certain that it would actually play this role. Only with time was the Organisation accepted as the most neutral or least dangerous body in which to handle conflicts.

Although Africa gradually won the right to settle its own conflicts, this did not lead the great powers to refrain from all intervention. The quantity of arms supplied to Nigeria in its war against Biafra exceeded that received by both sides in the Congo almost a decade earlier. 
To play its role the OAU had to be unbiased. Unless both sides to any dispute felt they would receive a fair hearing and just consideration of their arguments in the African body, they would not entrust it with a matter that concerned them so intensely. The OAU could not expect successfully to ward off intervention while it or some of its members intervened in a local crisis. Its first duty was therefore self-discipline.

It was necessary in addition to convince the great powers that there was less to gain than to lose by mixing in African Affairs. Although the OAU could make its strength felt against its own members, this was insignificant when brought to bear against the leaders of the world blocs. No African-inspired policy of restraint could be imposed upon them, nevertheless the African body tried to establish a certainty of political expectation with regard to foreign intervention; involvement had been very expensive in the past; by supporting one faction or state, each power had made enemies of the other: too many embassies had been closed and relations severed to make this attractive, and the outcome of African crises was so unpredictable that often both blocs were losers. Thus, by forming a united front the OAU could reinforce its non-alignment message and show the great powers that even if intervention in Africa's affairs earned them the friendship of the side they supported, it could entail the opposition of the rest of the community.

Valuable as it was, this restricted variety of non-alignment was still largely defensive or negative. If Africa wished to stamp its influence on the world scene: it had to return somewhat to the original idea of non-alignment and seek a positive contribution. Very rarely since its inception had the OAU dealt with an issue that was not purely African. Disarmament had only been considered as it affected the continent, and when the threat of nuclearisation had receded, the issue was dropped. Even with other questions of a broader nature, there was always some connection with Africa.

A case in point was racial discrimination. This matter was usually seen in the context of a struggle against South Africa and other settler or colonial powers. Nevertheless, the African states also tried to erase the sequels of discrimination in their own countries or expressed deep concern' about the situation in the USA. A special resolution on racial discrimination was adopted at the Cairo assembly. It regretted the 'continuing manifestations of racial bigotry and racial oppression against Negro citizens of the United States of America'.

The Palestinian question became an ambiguous problem for the OAU. Although several of its members were thoroughly committed on the issue, for many of the other states it was largely marginal. They resisted being drawn into the campaign of the Arab countries and often maintained excellent relations with Israel, while Arab leaders launched attacks against Israel as an imperialist and neo-colonialist stooge, drawing close parallels between their struggle against Israel and Africa's struggle against colonialism.

When it came to issues that were strictly non-African, although of crucial importance for the peace and security of the world, the OAU consistently remained on the side-lines. A notable precedent was made at the Accra Assembly when certain states tried to include items on Kashmir and Vietnam on the agenda. The preparatory meeting of the Council of Ministers refused to recommend any resolution on these two points because they were Asian issues. This decision was maintained by the Assembly which added that the items could best be discussed at the forthcoming Afro-Asian Conference.

In a general perspective, however, the member states felt that their existing problems: decolonisation, internal order and economic development, absorbed enough of their efforts to allow a little time for the adoption of policy positions on various fronts of international concerns. It was, in a way, far more difficult to find a common denominator to African unity, or to establish a joint African policy on other matters. Moreover any pronouncement on external issues might cost African sympathy and support for its primary aims. Thus it was agreed to keep them out of the $O A U$, let each member go its own way within a broad spectrum of attitudes and, if need be, have the issues dealt with in other forums.

\section{The United Nations and the Third World: preventive diplomacy}

If non-alignment is, on the one hand, a product of the balance between the super-powers, the Third World states in turn have affected this balance by playing a limited but very important arms control' role. Their attitude towards systemic stability comes in response to two conditions: 
a. the problems of the non-Western states tend to spill over into the international arena. This may result from the disintegration of a state, as happened in the Congo in 1960; in the resultant attempts to reunify it, the competing factions turned to outside help. Or it may be due to a clash of regional states that have allies in the different super-power blocs.

b. these types of problems tend to attract the Soviet Union and the United States, thus leading to a possible confrontation. The two super-powers are attracted because the outcome of these problems may be to bring to power a group one country likes and the other dislikes, or a regional expansion that may benefit one and hurt the other.

Thus the conflicts that arose on the peripheries of the cold war have tended to be drawn into the extensive confrontations of the two superpowers. In such situations outside of what might be called the cold war zone, where a threat to the peace of the world developed, the Third World Countries have played their role through the United States.

When it was formed, the UN reflected the war-time hopes that, once victory over Germany had been won, great power co-operation would continue and peace would be maintained. As long as the two super-powers could maintain harmony, peace would be preserved. The security system was directed against the smaller nations; if they disturbed the peace, and if the great powers agreed to take punitive action, they would be squashed. The United Nations was, in the words of one delegate at its first conference. engaged in establishing a world in which the mice could be stamped out but in which the lions would not be restrained. However, as the number of newly independent members grew rapidly during the 1950's and 60's, the nature of the UN changed. If both the American and Soviet blocs had previously used the United Nations for their own cold war purposes, the neutral bloc now employed the organisation to erase the vestiges of Western colonialism as soon as possible. The Assembly was a particularly good forum in which to voice anti-colonial sentiments and to keep the pressure on the West by passing, or trying to pass - with the help of the communist bloc resolutions in favour of national selfdetermination.

To the non-aligned nations the UN was more than a political platform. It was also a shelter in which they sought refuge from great power pressure.
They thought of it as theirs, and they were determined to use it to remain non-aligned. The chief function of the United Nations, as far as the Third World was concerned, thus became one of preventive diplomacy - that is, the stabilisation of local conflicts before either of the superpowers could become involved and thereby provoke its anti-agonists' intervention was well. To state it negatively, preventive diplomacy was intended to keep American-Soviet clashes from extending beyond the cold-war zone. At the same time, by containing the cold war, it would safeguard the new nations' independence and permit them control over their own future. Thus the mice were to keep the lions apart before they began to grapple with each other, and trample the mice to death while they fought.

From the early 1960's onwards, however, the conditions for non-alignment changed rapidly:

a. the passing of bipolarity. As the blocs broke up and the super-powers increasingly recognised their need for some co-operation in order to preserve the peace. their competition for the allegiance of the third world countries declined. Indeed, instead of seeking their alignment, their non-alignment began in most cases to seem preferable.

b. the waning impact of economic aid. Both the US and the USSR had become more and more disenchanted with economic aid to the non-aligned nations. Economic development seemed so terribly slow, and the new nations were found to be very nationalistic and, therefore, resistant to attempts to convert foreign aid into foreign control.

c. Successful use, militancy. Many of the new nations' more militant leaders, whose interests were primarily in foreign policy rather than domestic problems and the difficult task of modernisation, were deposed by less militant leaders whose basic concern was their nation's development. To the degree that the super-powers also wished to avoid a confrontation, they had found their militant leadership more a liability than a tool for establishing their influence.

d. Kaleidoscopic Third World. The rapid multiplication of the new states meant that it became harder to describe the third world as if it were a monolith whose members all responded indentically to the external stimuli of great power conflict. Among the nonaligned states, a multitude of differences arose, including conflicting views on America, Russia and China. 


\section{Conclusion}

In some ways it is surprising that the new states exercise the degree of influence that they do. Unlike the larger European states, the nonWestern nations are not industrialised; indeed, even if they possess a sizeable population, their economically underdeveloped condition means that they are not powerful. Yet they are influential, and there are a number of reasons for this state of affairs. The first is precisely that these nations are new, non-Western, non-white, and excolonial. For an older, Western, White nation with a legacy of colonial control to attempt to coerce or use force against one of the new states is nearly impossible in an age when national self-determination is universally recognised. A second reason is that these new, highly nationalistic states can if need be organise a

\section{STATE}

CAPITAL

Algeria
Botswana
Burundi
Cameroon
Central African Re-
public
Chad
The People's Rep
of the Congo
Benin
Ethiopia
Equatorial Guinea
Gabon
Gambia
Ghana
Guinea
Ivory Coast
Kenya
Lesotho
Liberia
Libya
Malagasy Republic
Malawi
Mali
Mauritania
Mauritius
Morocco
Niger
Nigeria
Rwanda
Senegal
Sierra Leone
Somali Republic

long revolutionary war of defence. Before the French Revolution and the birth of nationalism, the lack of popular participation and involvement with the state meant that military conquest did not need to be followed by the task of pacification. Today, this task is so difficult that the cost of using force for this purpose tends to be very high, if not excessive. Thirdly - and Vietnam demonstrates this point - Western military doctrine and forces are orthodox, geared to fighting one another, not adapted to fighting guerrilla armies. Thus, the combination of the balance between the super-powers, Western inhibitions against using their superior power in such a way as to appear to be acting as bullies, and the capacity of the non-aligned to resist allows at least some of them to exercise a degree of influence disproportionate to their actual power.

\section{Colonial power}

INDEPEndence

$\begin{array}{ll}\text { France } & 1962 \\ \text { Britain } & 1966 \\ \text { Belgium } & 1962 \\ \text { France/Britain } & 1960 \\ & \\ \text { France } & 1960 \\ \text { France } & 1960 \\ & \\ \text { France } & 1960 \\ \text { France } & 1960 \\ & \\ \text { Spain } & 1968 \\ \text { France } & 1960 \\ \text { Britain } & 1965 \\ \text { Britain } & 1957 \\ \text { France } & 1958 \\ \text { France } & 1960 \\ \text { Britain } & 1963 \\ \text { Britain } & 1966 \\ & 1847 \\ \text { Italy } & 1951 \\ \text { France } & 1960 \\ \text { Britain } & 1964 \\ \text { France } & 1960 \\ \text { France } & 1960 \\ \text { Britain } & 1968 \\ \text { France/Spain } & 1956 \\ \text { France } & 1960 \\ \text { Britain } & 1960 \\ \text { Belgium } & 1962 \\ \text { France } & 1960 \\ \text { Britain } & 1961 \\ \text { Italy/Britain } & 1960 \\ & \end{array}$




$\begin{array}{ll}\text { Sudan } & \text { Khartoum } \\ \text { Swaziland } & \text { Mbabane } \\ \text { Tanzania } & \text { Dar es Salaam } \\ \text { Togo } & \text { Lomé } \\ \text { Tunisia } & \text { Tunis } \\ \text { Uganda } & \text { Kampala } \\ \text { United Arab Republic } & \text { Cairo } \\ \text { Upper Volta } & \text { Ouagadougou } \\ \text { Zaire } & \text { Kinshasa } \\ \text { Zambia } & \text { Lusaka }\end{array}$

Anglo Egyptian

1956

Britain 1968

Britain 1961

France 1960

France 1956

Britain 1962

Britain 1922

France $\quad 1960$

Belgium 1960

Britain 1964

\section{BIBLIOGRAPHY}

1. Kimche, d: The Atro-Asian Movement - Ideology and Foreign Policy of the Third World Jerusalem, 1973

2. Quaison-Sackey, A: Africa Unbound London, 1963

3. Lyon, P: Neutralism. Leicester. 1963

4. Musito, G. - C. M. and Rohio. S. W. Readings in African Political Thought London, 1975.

5. Liska. G.: Alliances and the Third World. Baltimore, 1968.

6. Spanier. J: Games Nations Play. London, 1972

7. Woronoff, J: Organising African Unity. New Jersey, 1970

8. Jansen, G. H.: Atro-Asia and Non-Alignment London, 1966

9. Promotion of co-operation between the Non-Aligned (Review of International Affairs, Vol 29 No 669, 20 February 1978).

10. Non-Alignment and the National Question in the Developing
Countries (Review of International Affairs, Vol 29 No 684,5 October 1978).

11. Reinforcing Solidarity and Co-operation in the Non-Aligned Movement (Review of International Affairs, Vol 29 No 675.20 April 1978)

12. Non-Alignment - A factor of International Stability (Review of International Affairs, Vol 29 No 668, 5 February 1978).

13. Non-Aligned Summit Conference - 5th Meeting. Colombo (Africa Research Bulletin, August 1-31, 1978).

14. Non-Aligned: Confrontation Course (Africa Confidential, Vol 17 No 17, 27 August 1978)

15. The Diffusion of Power and the Control of Force in a New International Order (Adelphi Papers. No 134, 1977)

16. The Soviet Union and the Non-Aligned (The World Today, 12/76).

17. Foreign Policy and Development Policy (International Affairs, October 1976 